\title{
Bupivacaine and botulinum toxin to treat comitant strabismus
}

\author{
Bupivacaína e toxina botulínica para tratamento de estrabismo comitante
}

luisa Moreira Hopker ${ }^{1}$, Priscila Fernandes Zaupa ${ }^{1}$, Acácio Alves de Souza lima Filho ${ }^{2}$, Monica Fialho Cronemberger ${ }^{1}$, Marcia Keiko Uyeno Tabuse ${ }^{1}$, Célia Regina Nakanami ${ }^{1}$, Norma Allemann ${ }^{3}$, Tomás Scalamandré Mendonça ${ }^{1}$

\begin{abstract}
Purpose: To evaluate the change in ocular motility and muscle thickness measured with ultrasonography after intramuscular injection of bupivacaine and botulinum toxin A.

Methods: Eight patients (five female) were enrolled to measure ocular motility prior and $1,7,30$ and 180 days after one injection of $2 \mathrm{ml}$ of $1.5 \%$ bupivacaine and $2.5 \mathrm{U}$ of botulinum toxin A in agonist and antagonist muscles, respectively, of eight amblyopic eyes. Muscle thickness was measured prior and on days 1,7 and 30 after injection using 10-MHz ultrasonography (eyelid technique).

Results: Mean change in alignment was 10 prism diopters after 180 days $(n=6)$. An average increase of $1.01 \mathrm{~mm}$ in muscle thickness was observed after 30 days of bupivacaine injection and $0.28 \mathrm{~mm}$ increase was observed after botulinum toxin A injection, as measured by ultrasonography. Lateral rectus muscles injected with bupivacaine had a mean increase of $1.5 \mathrm{~mm}$ in muscle thickness.

Conclusion: In this study, a change in ocular motility was observed after 180 days of intramuscular injection of bupivacaine and botulinum toxin in horizontal extraocular muscles. Overall, there was an increase of muscle thickness in both botulinum toxinum A and bupivacaine injected muscles after 30 days of injection when measured by ultrasonography. This change was more pronounced on lateral rectus muscles after bupivacaine injection.
\end{abstract}

Keywords: Oculomotor muscles; Strabismus/diagnosis; Strabismus/drug therapy; Esotropia/drug therapy; Botulinium toxins, type A/administration \&dosage; Botulinium toxins, type A/therapeutic use; Bupivacaine/therapeutic use; Bupivacaine/administration \& dosage; Injections, intramuscular; Ultrasonography

\section{RESUMO}

Objetivo: Avaliar a mudança na motilidade ocular e espessura dos músculos medida por ultrassonografia após injeção intramuscular de bupivacaína e toxina botulínica tipo A. Métodos: Oito pacientes (5 mulheres) foram incluidos para avaliar a mudança na motilidade ocular antes e após 1, 7, 30 e 180 dias da injeção de $2 \mathrm{ml}$ de bupivacaína 1,5\% e 2,5 U de toxina botulínica tipo A nos músculos agonista e antagonista, respectivamente, de 8 olhos amblíopes. A espessura muscular foi medida antes após 1, 7, 30 dias da injeção através de ultrassonografia ocular 10-MHz (técnica palpebral).

Resultados: A média de mudança no alinhamento ocular foi igual a 10 dioptrias prismáticas após 180 dias $(n=6)$. Foi observado um aumento médio de 1,01 $\mathrm{mm}$ na espessura muscular após 30 dias da injeção de bupivacaína e 0,28 mm após a injeção de toxina botulínica A medido pela ultrassonografia. Os músculos reto laterais injetados com bupivacaína tiveram um aumento médio de 1,5 mm na sua espessura.

Conclusão: Neste estudo, observou-se uma mudança no alinhamento ocular após 180 dias de injeção intramuscular de bupivacaína e toxina botulínica A. Em geral, houve um aumento da espessura muscular de ambos os grupos de músculos injetados com toxina botulínica A e com bupivacaína após 30 dias da injeção. Essa mudança foi mais pronunciada nos músculos retos laterais após a injeção de bupivacaína.

Descritores:Músculosoculomotores; Estrabismo/diagnostico; Estrabismo/quimioterapia; Esotropia/quimioterapia; Toxinas botulínicas tipo Avadministração \& dosagem; Toxinas botulínicas tipo A/uso terapêutico; Bupivacaína/uso terapêutico; Bupivacaína/administração \& dosagem; Injeções intramusculares; Ultrassonografia

\section{INTRODUCTION}

Strabismus treatment traditionally includes the correction of refractive errors, amblyopia treatment, chemical weakening of the muscles with botulinum toxin A or a surgical procedure.

Surgery is a procedure that presents some drawbacks such as conjunctival scars and changes in rotational forces which may limit ocular motility ${ }^{(1-3)}$. For this reason some attention has been given to new substances such as botulinum toxin A and more recently, bupivacaine. These medications may promote changes in muscle biomechanics not attainable with surgery ${ }^{(4)}$. These changes include modulation of muscle force without permanently changing the muscle insertion on the eye ${ }^{(5)}$.

Bupivacaine is an anesthetic drug that has been used in peribulbar and retrobulbar anesthesia for a long time and presents few complications $^{(6)}$. Many studies have shown that muscles in which bupivacaine was accidentally injected such as in anesthetic blocks for cataract surgery, presented a change in ocular alignment with subsequent diplopia ${ }^{(7)}$. Hypertrophy of such muscles after bupivacaine injection has been described ${ }^{(8-10)}$. Bupivacaine affects the extraocular muscles through selective damage to fibers while preserving cellular support structures, nerves and satellite cells. Through growth factors released by damaged tissue, the satellite cells proliferate and form new muscle fibers repairing the initial damage and causing muscle hypertrophy. This hypertrophy increases the stiffness and muscle contractility with consequences in ocular alignment. These changes are permanent, with alignment stability and muscle hypertrophy reported up to 500 days after injection ${ }^{(11)}$.

For the purpose of ocular alignment, bupivacaine should be injected with an aid of a electroneuromiography (EMG) needle under topical anesthesia, used to determine the adequate position of the needle which would be used to inject the substance intramuscularly, in the posterior third of the muscle ${ }^{(4,11,12)}$.
Funding: No specific financial support was available for this study.

Disclosure of potential conflicts of interest: L.M.Hopker, None; P.F.Zaupa, None; A.A.S.Lima Filho, None; M.F.Cronemberger, None; M.K.U.Tabuse, None; C.R.Nakanami, None; N.Allemann, None; T.S.Mendonça, None.

Comissão de Ética e Pesquisa Universidade Federal de São Paulo: Aprovado 1148/10.

Correspondence address: Luisa Moreira Hopker. Rua Munhoz da Rocha 98, Apto. 31 - Curitiba (PR) 80035-000 - Brazil - E-mail: luhopker@gmail.com 
The present study intends to analyze the effect of bupicavaine and botulinum toxin A injections in extraocular muscles with comitant strabismus, evaluating ocular motility and extraocular muscle thickness.

\section{METHODS}

In this study we prospectively enrolled 8 patients with comitant strabismus and either amblyopia or poor vision in one eye. These patients underwent injections of $2 \mathrm{ml}$ of $1.5 \%$ bupivacaine in the lateral rectus (LR) if had esotropia or in the medial rectus (MR) if had exotropia and $2.5 \mathrm{U}$ botulinum toxin $\mathrm{A}$ in the MR if had esotropia or in the LR if had exotropia. The protocol was approved by the Ethics Committee - Investigational Review Board of the Federal University of São Paulo, Brazil.

The criteria for enrollment in the study were: poor vision in one eye and comitant strabismus and no previous surgery or botulinum toxin A injections. All patients had visual acuity lower than 0.5 in the worst eye. Three of them had exotropia and 5 esotropia.

One ophthalmologist (TSM) used EMG to localize the posterior third of the horizontal rectus muscle where the injection of $2 \mathrm{ml}$ of $1.5 \%$ bupivacaine was performed under topical anesthesia (proximetacaine). At least one third of the medication was injected along the needle trajectory while the syringe was being withdrawn. The injection was performed in the LR in case of esotropia and in the MR in case of exotropia. Botulinum toxin A was subsequently administered using Mendonça's forceps in the contralateral horizontal rectus muscle ${ }^{(13)}$. Botulinum toxin A was diluted using $100 \mathrm{U}$ ampoule and $2 \mathrm{ml}$ of $0.9 \%$ saline solution. Subsequently $2.5 \mathrm{U}$ were injected into the MR in esotropic patients and into the $L R$ in the exotropic ones.

All patients underwent ocular ultrasonography (USG) of both eyes once before the procedure, and repeated 7 and 30 days after the procedure, to determine the thickness of all extraocular muscles. All measurements were performed by the same examiner (NA) using a $10-\mathrm{MHz}$ transducer (Ultrascan, Alcon), and eyelid contact method (ultrasound gel was used as a coupling media), with patient's eye aligned in primary position. One eye was examined at the time and the patient was asked to fixate on a target with that eye to ensure alignment.

Patients underwent a comprehensive ophthalmological exam before the procedure. Clinical examination was performed after 1, 7, 15,30 days and then monthly until 180 days to determine eye alignment, versions and the presence of complications. All the motility measurements were performed by the same examiner (LMH) using the Krimsky method or the cover/uncover method when the patient was able to fixate a target at distance.

Both examiners for ocular motility exam and ultrasonography (LMH and NA) did not have access to medical records with previous measurements until all data was collected.

\section{RESULTS}

The eight patients who underwent injection of bupivacaine and botulinum Toxin A presented average age of 24.5 years (range 18 to 53 years), three were male (five, female).

Five presented the primary diagnosis of esotropia, four of them had infantile esotropia and amblyopia, and one had esotropia secondary to macular scar due to toxoplasmosis. The other three patients had exotropia. One of which had congenital cataract that had been operated and manifest nystagmus, other had poor vision in one eye due to a macular scar subsequent to congenital toxoplasmosis and the last one had a trauma in childhood with subsequent glaucoma and low vision.

Table 1 summarizes the changes in alignment deviation during the follow-up. Four patients (2, 3, 6 and 8$)$ developed a transitory vertical deviation due to the effect of the botulinum toxin $A$, which was recovered by day 180 . Ptosis of $1 \mathrm{~mm}$ was present in patients 1 (Figure 4), 5, 7 and 8 at the $7^{\text {th }}, 15^{\text {th }}$ and $30^{\text {th }}$ days of follow-up visit. Patient 2 presented a $2 \mathrm{~mm}$ ptosis and patient 4, $4 \mathrm{~mm}$ ptosis, presented at the $7^{\text {th }}, 15^{\text {th }}, 30^{\text {th }}$ and $60^{\text {th }}$ days of follow-up visit. The overall mean change in deviation was 10 prism diopters at the $180^{\text {th }}$ day visit. Patients 4 (Figure 5) and 8 had an increase in deviation on day 1 . All patients had the smallest angle of deviation at days 15 and 30. Patients 2, 3 and 4 had a higher deviation on the $60^{\text {th }}$ day than the previous visit, with a decrease on deviation the $180^{\text {th }}$ day. Patients 5 and 6 were excluded due to lack of follow-up data at the $60^{\text {th }}$ and $180^{\text {th }}$ days visit.

Figure 1 and table 2 show the thickness of the muscle injected with botulinum toxin type A measured by USG before the injection and after 7 and 30 days of the procedure. Figure 2 and table 3 show the thickness of the muscle injected with bupivacaine also measured by USG before the injection and after 7 and 30 days. Patient 5 undertook the USG exam 60 days after injection instead of 30 because of a not related clinical intervention. Figure 3 shows the muscle thickness before and after injection in each group of muscles - LR and MR.

Ultrasonography showed an average increase in thickness of the muscle injected with Bupivacaine on the $7^{\text {th }}$ day of $0.43 \mathrm{~mm}$. The mean increase of muscle thickness after 30 days injection of bupivacaine was equal of $1.01 \mathrm{~mm}$, and after botulinum toxin A injection was equal of $0.28 \mathrm{~mm}$. When comparing before and after injection, an increase in thickness of the LR injected with botulinum toxin $A$ $(0.6 \mathrm{~mm})$ and with bupivacaine $(1.5 \mathrm{~mm})$ was observed in thickness for each group of muscles. There was no increase in thickness of the MR injected with bupivacaine, and a small increase in the botulinum toxin A MR injected group (0.1 mm).

One patient (patient 5) presented a retrobulbar hemorrhage during bupivacaine injection in the MR. The complication was treated using compressive bandage of the eye with adequate control of IOP and proptosis. After 60 days the patient showed no change in visual acuity and no optic disc abnormality at fundoscopy, but a decrease in the pupillary response with medium mydriasis.

Table 1. Change in deviation in the study population presenting comitant strabismus before and after injection of bupivacaine and botulinum toxin in prism diopters (PD)

\begin{tabular}{|c|c|c|c|c|c|c|c|c|}
\hline Patient & $\begin{array}{l}\text { Initial deviation } \\
\text { (PD) }\end{array}$ & $\begin{array}{c}\text { Day } 1 \\
\text { (PD) }\end{array}$ & $\begin{array}{c}\text { Day } 7 \\
\text { (PD) }\end{array}$ & $\begin{array}{l}\text { Day } 15 \\
\text { (PD) }\end{array}$ & $\begin{array}{c}\text { Day } 30 \\
\text { (PD) }\end{array}$ & $\begin{array}{c}\text { Day } 60 \\
\text { (PD) }\end{array}$ & $\begin{array}{l}\text { Day } 180 \\
\text { (PD) }\end{array}$ & $\begin{array}{l}\text { Variation } \\
\text { (PD) }\end{array}$ \\
\hline 1 & ET60HTE10 & ET50HTE10 & ET45HTE10 & ET30HTE8 & ET25HTE8 & ET45HTE10 & ET45HTE8 & 15 \\
\hline 2 & ET20 & ET2OHTE4 & ET20 & ET15HTE2 & ET10 & ET20 & ET15 & 5 \\
\hline 3 & XT45 & XT45 & XT50HTD6 & XT30 & XT30 & XT40 & XT30 & 15 \\
\hline 4 & ET50 & ET56 & ET50 & HTE4 & HTE6 & ET35HTE6 & ET30 & 20 \\
\hline 5 & XT62 & XT60 & XT50 & XT45 & - & XT56 & - & - \\
\hline 6 & ET20 & ET20 & ET15 & ET4HTE8 & ET15HTE2 & - & - & - \\
\hline 7 & XT45HoTD10 & XT40 HoTD10 & XT25HoTD8 & XT20HoTD10 & XT30HoTD10 & XT30 HoTD10 & XT40 HoTD10 & 5 \\
\hline 8 & ET20 & ET25 & ET12 & ET10HTE2 & ET20 & ET20 & ET20 & 0 \\
\hline
\end{tabular}




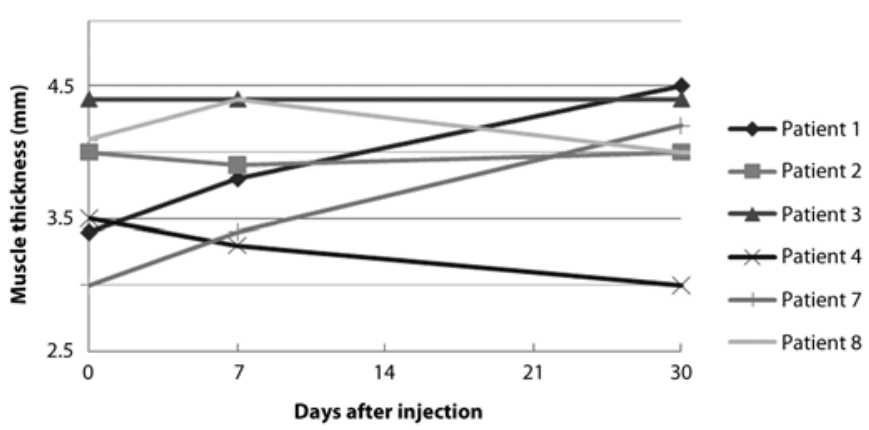

Figure 1. Change in muscle thickness in millimeters $(\mathrm{mm})$ measured by ocular ultrasonography after botulinum toxin A injection in comitant strabismus.

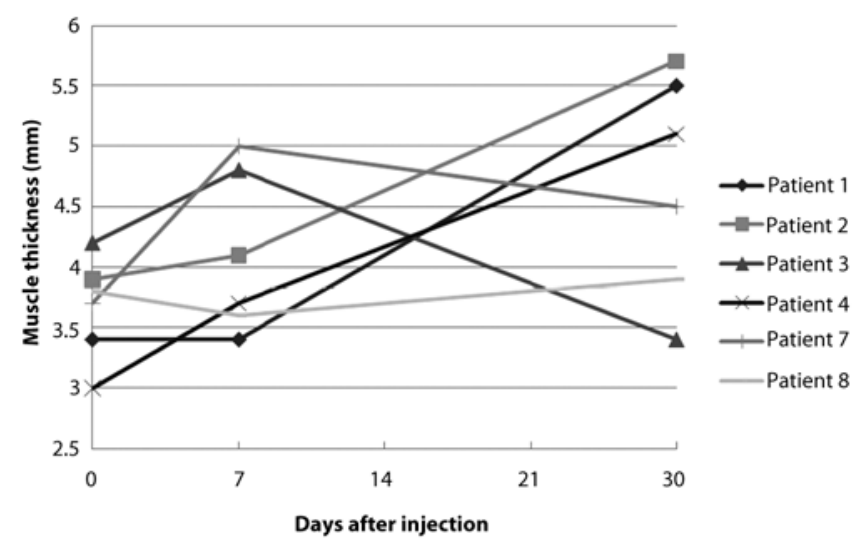

Figure 2. Change in muscle thickness in milimeters $(\mathrm{mm})$ measured with ocular ultrasonography after bupivacaine injection.

\section{DISCUSSION}

In this study we chose to inject bupivacaine and botulinum toxin A only once in patients who had not been operated on before. This protocol was performed to evaluate the effect of one injection of a specific concentration and volume of bupivacaine (2 $\mathrm{ml}$ in 1.5\%) and botulinum toxin A ( $2.5 \mathrm{U})$. In a previous study some patients had been operated on before the procedure and different dosages of bupivacaine and botulinum toxin A were administered ${ }^{(4)}$.

Scott et al., have demonstrated that the alignment achieved with the injection of bupivacaine in the agonist muscle and botulinum toxin A in the antagonist muscle was 19.7 prism diopters in comitant strabismus ${ }^{(4)}$. Another study demonstrated changes of 6.1 prism diopters in esotropias treated only with bupivacaine in the lateral rectus of the affected eye ${ }^{(11)}$. We found an average correction of 10 prism diopters over 180 days. It is believed that this correction was due not only to the botulinum toxin A, since it was applied in low doses, though it allows a temporary paresis of the muscle while the antagonist muscle is being reloaded after bupivacaine application ${ }^{(4)}$.

We observed that patients 1, 3 and 4, who presented greater change in alignment, showed paresis of the two horizontal muscles (medial and lateral rectus) injected with medications during the regeneration period of the muscle. The same observation was stated in a previous study ${ }^{(14)}$. All patients had the smallest deviation between 15 and 30 days after injection which is consistent with the peak of action of botulinum toxin $\mathrm{A}$.

All patients from this series had low visual acuity in one eye, 0.5 logMAR or worse, thus Krimsky test was used to determine the angle of strabismus in most of them, due to their unsteady fixation. This method has already been described as variable even for experien-

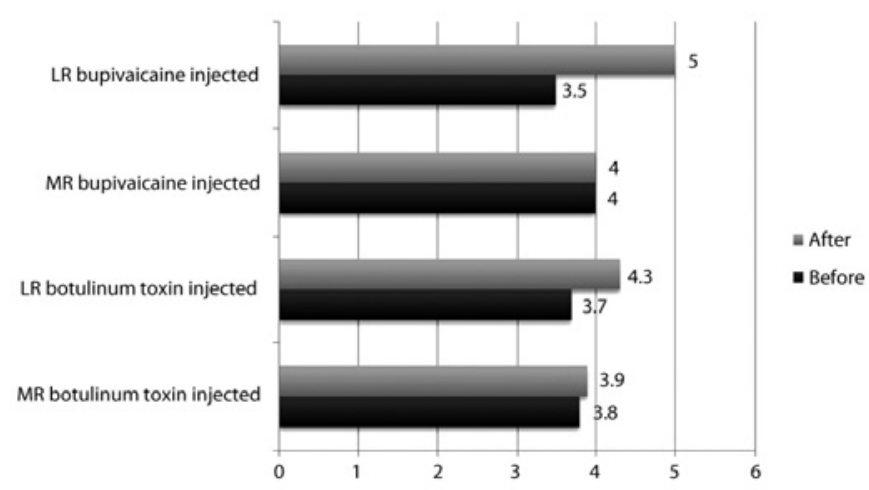

Figure 3. Muscle thickness of medial rectus (MR) and lateral rectus (LR) before and after injection of botulinum toxin $A$ and bupivacaine in millimeter $(\mathrm{mm})$

ced examiners ${ }^{(15)}$, reason that could explain the variability on some measurements, such as patients 4 and 8 on the $1^{\text {st }}$ day, and patients $2,3,4$ on the $60^{\text {th }}$ day.

It is being advocated that intramuscular injection of bupivacaine induces a degeneration of muscle fibers that will end up activating satellite cells and regeneration of new muscle fibers between the $10^{\text {th }}$ and $20^{\text {th }}$ days after injection, continuing to build a muscle with greater contractility and size at least until the $180^{\text {th }}$ day ${ }^{(11)}$. Few studies report the clinical effect of bupivacaine to treat strabismus, thus it is still unclear the exact onset of its clinical effect and peak of action. Scott et al., reported an onset of clinical effect after 16 days of bupivacaine intramuscular injection ${ }^{(11)}$. Botulinum toxin A has a peak of action between 1 to 2 weeks after injection and will last until an average of 3 months ${ }^{(16)}$. That difference in time of action could explain the variability on some measurements, such as for patients 2, 3, 4 on the 60-day visit.

We observed greater technical difficulty in injecting bupivacaine into the medial rectus vs. the lateral rectus. This might have influenced the result in patient 5, who presented a complication of the procedure - retrobulbar hemorrhage; that resulted in an abnormal pupil but no deterioration in vision. Thus far, considering complications arising after the application of intramuscular bupivacaine, a previous study reported a case of orbital inflammation, which spontaneously resolved ${ }^{(4)}$.

As complications related to the intramuscular injection of botulinum toxin A, we observed ptosis of the upper eyelid and vertical deviation. Ptosis was present in $75 \%$ of the patients and fully recovered by 180 days after injection, compared to previous studies that report up to $53 \%$ of the patients ${ }^{(14)}$. Vertical deviation was described in previous studies with a frequency of 2 to $16 \%{ }^{(14)}$ and the time to recovery around 6 weeks. In our series, vertical deviation occurred in $62.5 \%$ of the patients, all of them recovered by 180 days.

In the present series, there was an increase in muscle thickness for both groups, injected with botulinum toxin A and bupivacaine, but the second group presented a greater amount of response. Previous studies showed increase in muscle volume after 33 days ${ }^{(11)}$ and up to 350 days $^{(4)}$ of bupivacaine injection using the imaging method magnetic resonance imaging (MRI). Although USG and MRI are two different imaging methods, both showed increased muscle thickness after the injection of bupivacaine. Both methods had been used to determine extraocular muscle thickness. Ultrasonography is considered a more accessible and cost-effective imaging method to evaluate extraocular muscle thickness, with less contraindication, allowing considerations about internal reflectivity ${ }^{(17)}$. In a previous report using USG and MRI techniques to determine extraocular muscle thickness, the average thickness for each rectus muscle was found to be similar, with reference that the ultrasound related measurements should be 

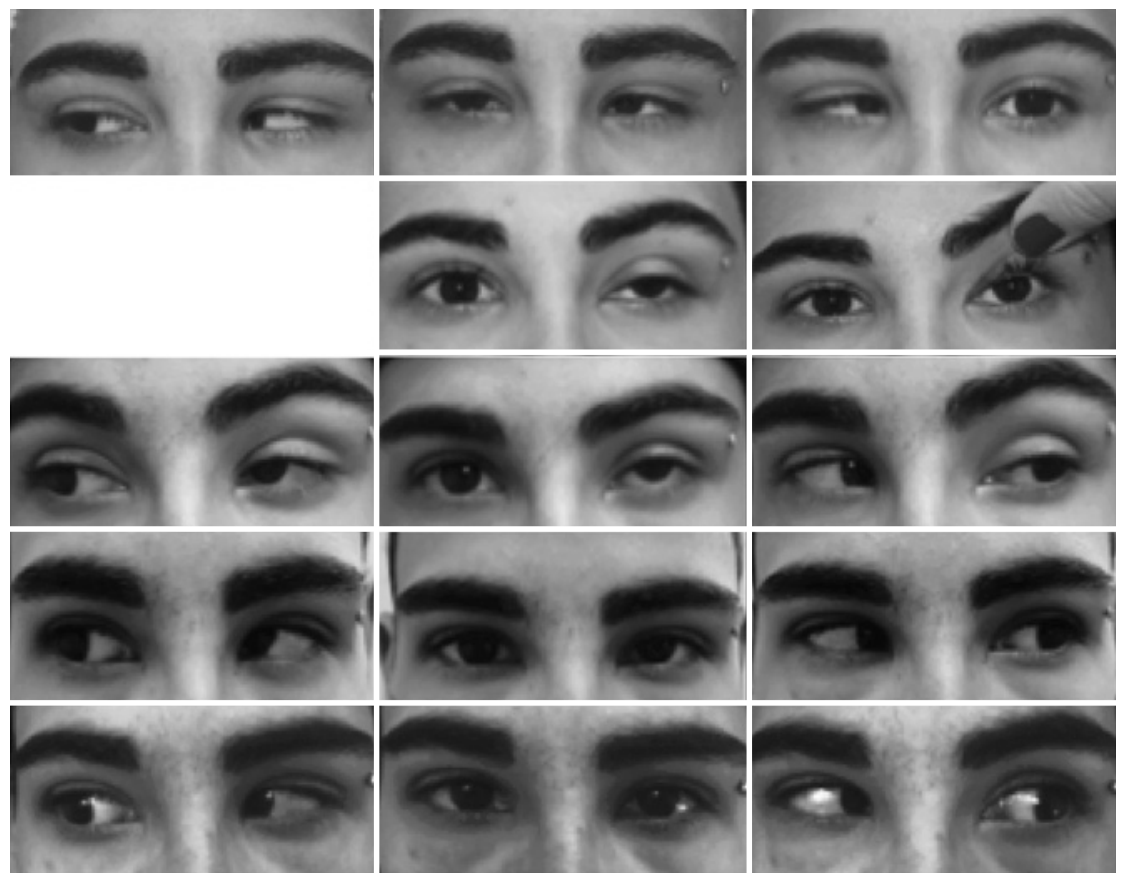

Figure 4. (patient 1): First row: Before injection of Bupivacaine and Botulinum toxin ET50. Second row: $15^{\text {th }}$ day of follow-up HTE4. Third row: $30^{\text {th }}$ day of follow-up, HTE6. Fourth row: $60^{\text {th }}$ day of follow-up,ET35HTE6. Fifth row: $180^{\text {th }}$ day of follow-up, ET30.
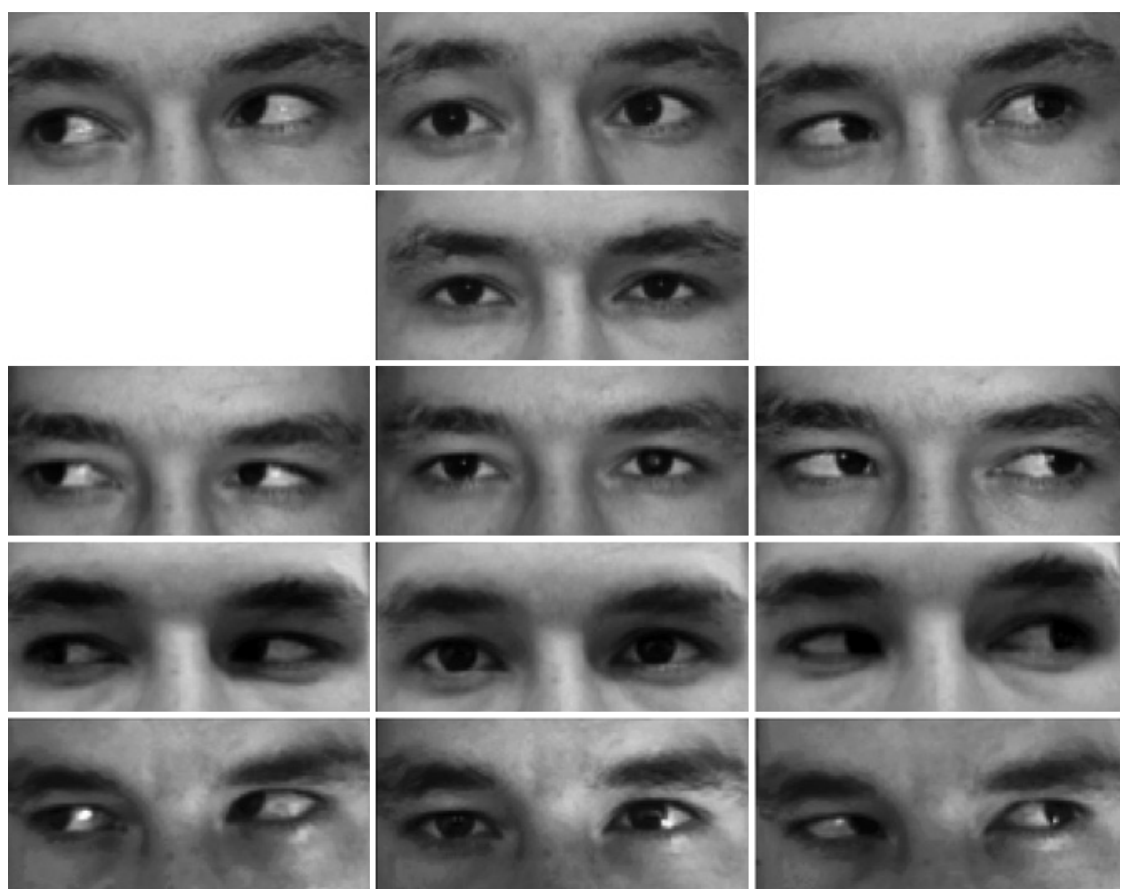

Figure 5. (patient 4): First row: Before injection of Bupivacaine and Botulinum toxin ET60HTE10. Second row: $15^{\text {th }}$ day offollow-upET30HTE8. Third row: $30^{\text {th }}$ day offollow-up, ET25HTE8. Fourth row: $60^{\text {th }}$ day of follow-up,ET45HTE10. Fifth row: $180^{\text {th }}$ day of follow-up, ET45HTE8.

interpreted cautiously ${ }^{(17)}$. Patients 4 and 8 presented a decrease in muscle thickness after botulinum toxin A injection, and patient 3 had a decrease in muscle thickness after bupivacaine injection when measured by USG. These findings could be explained due to the intrinsic variability of the ultrasonographic method for determining muscle thickness.
When compared with previous normal values for muscle thickness in patients without strabismus, measured by a similar method (10 MHz ultrasound, Mentor TM Advent Ultrasonic diagnostic imaging system), the present series presented a higher average of thickness both for medial rectus ( $3.9 \mathrm{~mm}$ vs $3.5 \mathrm{~mm}$ ) and for lateral rectus before injection (3.6 mm vs. $3 \mathrm{~mm})^{(18)}$. This finding could be explained 
Table 2. Variation in muscle thickness determined by ocular ultrasonography after botulinum toxin injection in comitant strabismus in milimeters $(\mathrm{mm})$

\begin{tabular}{lcccc}
\hline & \multicolumn{4}{c}{$\begin{array}{c}\text { Muscle thickness measurement after } \\
\text { botulinum toxin injection }(\mathbf{m m})\end{array}$} \\
\cline { 2 - 5 } Patient & Initial & Day 5 & Day 30 & Variation \\
\hline 1 & 3.4 & 3.8 & 4.5 & 1.1 \\
2 & 4.0 & 3.9 & 4.0 & 0 \\
3 & 4.4 & 4.4 & 4.4 & 0 \\
4 & 3.5 & 3.3 & 3.0 & -0.5 \\
7 & 3.0 & 3.4 & 4.2 & 1.2 \\
8 & 4.1 & 4.4 & 4.0 & -0.1 \\
\hline
\end{tabular}

Table 3. Variation in muscle thickness determined by ocular ultrasonography after bupivacaine injection in comitant strabismus in milimeters $(\mathrm{mm})$

\begin{tabular}{lcccc}
\hline & \multicolumn{4}{c}{$\begin{array}{c}\text { Muscle thickness measurement after } \\
\text { bupicavaine injection }(\mathbf{m m})\end{array}$} \\
\cline { 2 - 5 } Patient & Initial & Day $\mathbf{7}$ & Day $\mathbf{3 0}$ & Variation \\
\hline 1 & 3.4 & 3.4 & 5.5 & 2.1 \\
2 & 3.9 & 4.1 & 5.7 & 1.8 \\
3 & 4.2 & 4.8 & 3.4 & -0.8 \\
4 & 3.0 & 3.7 & 5.1 & 2.1 \\
7 & 3.7 & 5.0 & 4.5 & 0.8 \\
8 & 3.8 & 3.6 & 3.9 & 0.1 \\
\hline
\end{tabular}

by a muscular contracture and/or by the abnormal position of the eye due to comitant strabismus. When compared the increase in muscle thickness of LR with MR after injections, we observed that both LR injected with botulinum toxin $A$ and bupivacaine had an increase in thickness, while MR muscles only showed a small increase when injected with botulinum toxin A. No change was observed after bupivacaine injection in MR. Injecting the posterior third of the MR was technically more difficult than injecting into the LR. It is possible that the bupivacaine was not accurately placed in the MR, which can explain the difference in measurements comparing the two groups of muscles. The importance of the injection site has previously been emphasized ${ }^{(4)}$

Ultrasonography is considered a dynamic exam, and even when performed by the same trained examiner may produce variable results in extraocular muscle thickness especially in patients with strabismus. This could be possibly influenced by the position of the eye and the amount of contracture of the muscle. To our knowledge, no previous studies determine normal values for extraocular muscle thickness in adult patients with strabismus.

Best effects in comitant strabismus treatment are achieved with bupivacaine in concentrations of 3.0\%,2.0\% and 1.5\% and a volume of between 2 and $4 \mathrm{ml}$ injected into the target muscle ${ }^{(4)}$. In this study, the volume of $2 \mathrm{ml}$ and the concentration of $1.5 \%$ bupivacaine were used to assess the resulting average correction for this given volume and concentration. We believe that future studies should vary concentration and volume to observe differences in the changes in ocular alignment.

\section{CONCLUSION}

To date, few reports addressed the treatment of strabismus with bupivacaine and botulinum toxin A and the measurement of muscle thickness after its injection. In this study we observed a mean change of 10 diopters of ocular alignment after 180 days of injection. Overall, there was an increase of muscle thickness after both botulinum toxinum A and bupivacaine injections after 30 days. This change was more pronounced on lateral rectus muscles after bupivacaine injection. This study demonstrates that the injection of bupicavaine associated with botulinum toxin A in extraocular muscles may be useful for the treatment of small to moderate horizontal strabismus, as an option for the surgical treatment.

\section{AKNOWLEDGEMENTS}

The authors thank Dr Alan Scott (Smith-Kettlewell Institute for Visual Sciences, San Francisco,California) for the helpful discussion that originated this research.

\section{REFERENCES}

1. Clark RA, Demer JL. Rectus extraocular muscle pulley displacement after surgical transposition and posterior fixation for treatment of paralytic strabismus. Am J Ophthalmol. 2002;133(1):119-28

2. Livir-Rallatos G, Gunton $\mathrm{KB}$, Calhoun $\mathrm{JH}$. Surgical results in large-angle exotropia. J AAPOS. 2002;6(2):77-80

3. Trigler $\mathrm{L}$, Siatkowski RM. Factors associated with horizontal reoperation in infantile esotropia. J AAPOS. 2002;6(1):15-20.

4. Scott $A B$, Miller JM, Shieh KR. Treating strabismus by injecting the agonist muscle with bupivacaine and the antagonist with botulinum toxin. Trans Am Ophthalmol Soc. 2009;107:104-9.

5. Anderson BC, Christiansen SP, Grandt S, Grange RW, McLoon LK. Increased extraocular muscle strength with direct injection of insulin-like growth factor-I. Investigative Ophthalmol Visual Sci. 2006:47(6):2461-7.

6. Wong DH. Regional anaesthesia for intraocular surgery. Can J Anaesth. 19931;40(7): 635-57.

7. Goldschmidt M, Scott AB. Avaliação da motilidade extrínseca ocular de pacientes facectomizados sob anestesia retrobulbar. Arq Bras Oftalmol. 1994;57(2):114-6.

8. Hoyt CS. A problem! Now a solution? Br J Ophthalmol. 2007;91(2):127-8.

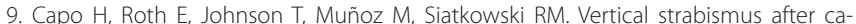
taract surgery. Ophthalmology. 1996;103(6):918-21. Comment in: Ophthalmology. 1996;103(10):1521-2. Ophthalmology. 1997:104(2):171.

10. Hamed LM, Mancuso A. Inferior rectus muscle contracture syndrome after retrobulbar anesthesia. Ophthalmology. 1991;98(10):1506-12.

11. Scott $A B$, Alexander DE, Miller JM. Bupivacaine injection of eye muscles to treat strabismus. Br J Ophthalmol. 2007;91(2):146-8. Comment in: Br J Ophthalmol. 2007;91(2): $127-8$.

12. Scott AB, Miller JM, Shieh KR. Bupivacaine injection of the lateral rectus muscle to treat esotropia. J AAPOS. 2009;13(2):119-22.

13. Mendonça TF, Cronemberger MF, Lopes MC, Nakanami CR, Bicas HE. [Electromyograph assistance and Mendonça's forceps - a comparison between two methods of botulinum toxin A injection into the extraocular muscle]. Arq Bras Oftalmol. 2005;68(2):245-9. Portuguese.

14. Rowe F, Noonan C. Complications of botulinum toxin $A$ and their adverse effects. Strabismus. 2009;17(4):139-42.

15. Choi RY, Kushner BJ. The accuracy of experienced strabismologists using the Hirschberg and Krimsky tests. Ophthalmology.1998;105(7):1301-6.

16. Dutton J, Fowler A. Botulinum toxin in ophthalmology. Surv Ophthalmol. 2007;52(1): 13-31.

17. Demer $J$, Kerman BM. Comparison of standardized echography with magnetic resonance imaging to measure extraocular muscle size. Am J Ophthalmol. 1994;118(3): 351-61.

18. Imbrasiené D, Jankauskiené J, Stanislovaitiené D. Ultrasonic measurement of ocular rectus muscle thickness in patients with Graves' ophthalmopathy. Medicina (Kaunas). 2010;46(7):472-6. 